\title{
PENGARUH KARAKTERISTIK PERSONALITAS MANAJER TERHADAP HUBUNGAN ANTARA PARTISIPASI DALAM PENYUSUNAN ANGGARAN DENGAN KINERJA MANAJERIAL
}

\author{
Endang Raino Wirjono \\ Agus Budi Raharjono \\ Universitas Atma Jaya Yogyakarta
}

\begin{abstract}
This research examined the effects of budget participation on performance of manager in firms. Prior studies in participative budgeting suggest that personality characteristic is potentially important explanatory variables to motivate manager achieving good performance. Data were collected from 85 managers of firms in Yogyakarta. Results of this study indicated that interaction between need of independence and participation had significant impact on managerial performance. This research also proved that interaction between need of authority and participation in setting budgeting had significant impact on managerial performance.
\end{abstract}

Keywords: need of independence, need of authority, participative budgeting, managerial performance

\section{PENDAHULUAN}

Dalam menjalankan sebuah organisasi, ada berbagai fungsi yang harus dilakukan oleh seorang manajer. Fungsi-fungsi tersebut adalah perencanaan (planning), pengendalian (controlling), dan pengambilan keputusan (decision making) (Usry et al., 2002). Perencanaan sebagai titik tolak menjalankan kegiatan organisasi, memegang peranan yang sangat penting. Berdasarkan jangka waktunya, perencanaan dapat dibedakan menjadi perencanaan jangka panjang dan jangka pendek. Perencanaan jangka panjang perusahaan tertuang dalam visi, misi, strategi dan program, sedangkan perencanaan jangka pendek akan diturunkan berdasar perencanaan jangka panjang. Perencanaan jangka pendek yang disajikan dalam bentuk angka-angka disebut dengan anggaran.

Perusahaan memerlukan anggaran sebagai salah satu komponen penting agar tetap survive dalam lingkungan bisnis yang cepat berubah seperti sekarang ini. Sebuah organisasi memerlukan anggaran untuk menerjemahkan seluruh strategi menjadi rencana dan tujuan jangka pendek dan jangka panjang (Hansen dan Mowen, 2004).

Anggaran dibuat atau disiapkan oleh perusahaan baik pada level korporat, departemen, divisi maupun berbagai fungsi, misalnya penjualan, produksi, riset dan sebagainya (Hansen dan Mowen, 2004). Anggaran merupakan gambaran kuantitatif dari tujuan-tujuan manajemen dan menjadi alat untuk menentukan kemajuan dalam mencapai tujuan tersebut. Anggaran juga menjadi metode penerjemahan tujuan dan sasaran organisasi menjadi hal yang operasional (Pasoloran, 2002). Selain itu, menurut Kennis (1979), anggaran tidak hanya merupakan perencanaan keuangan dari pusat-pusat pertanggungjawaban dalam perusahaan tetapi juga menjadi alat pengendalian, koordinasi dan komunikasi.

Proses penyusunan anggaran merupakan kegiatan yang penting dan melibatkan berbagai pihak baik manajer tingkat atas maupun manajer tingkat bawah. Para manajer akan memainkan peranan dalam mempersiapkan dan mengevaluasi berbagai alternatif dari tujuan anggaran, ketika anggaran digunakan sebgaai tolok ukur kinerja manajer (Leslie, 1992). Pada dasarnya, penyusunan anggaran dapat dibagi menjadi dua yaitu penganggaran partisipatif 


\section{Pengaruh Karakteristik Personalitas Manajer (Endang Raino Wirjono dan Agus Budi Raharjono)}

(bottom-up) yang disusun dengan memberikan kesempatan bagi manajer level bawah untuk berpartisipasi dalam pembentukan anggaran; dan penganggaran top-down, yang disusun dengan tidak melibatkan partisipasi bawahan secara signifikan (Alim, 2002).

Searfoss dan Monczka (1973) menyatakan bahwa anggaran disusun utnuk mengkuantifikasikan rencanarencana organisasi dan mengendalikan pergerakan organisasi agar tetap berada dalam jalurnya. Sedangkan Covaleski et al. (2003) menyatakan bahwa penganggaran berhubungan dengan akuntansi biaya, akuntansi pertanggungjawaban, pengukuran kinerja dan kompensasi. Covaleski et al. (2003) juga menyatakan penganggaran digunakan untuk berbagai tujuan meliputi perencanaan, pengorganisasian aktivitas-aktivitas organisasi, pengalokasian sumber daya, pemotivasian karyawan dan pengejawantahan konformitas dengan norma-norma sosial. Bahkan Luft dan Shields (2003) menyatakan bahwa penganggaran merupakan salah satu topik penelitian paling menarik dalam akuntansi manajemen.

Penelitian mengenai anggaran sebagian besar membahas mengenai penyusunan anggaran partisipatif. Beberapa peneliti menemukan bahwa partisipasi dalam penyusunan anggaran memiliki pengaruh positif terhadap kinerja dan motivasi kerja manajerial (Govindarajan, 1986; Leslie, 1992).

Akan tetapi, penelitian mengenai partisipasi penyusunan anggaran terhadap kinerja manajerial masih menunjukkan hasil yang bertentangan (Hariyanti dan Nasir, 2002).

\section{TINJAUAN LITERATUR DAN PENGEMBANGAN HIPOTESIS}

\subsection{Bukti-Bukti Empiris Penelitian Sebelumnya}

Penyusunan anggaran dan pelaksanaan kegiatan penganggaran, pada dasarnya terletak pada pimpinan tertinggi. Namun demikian, tugas menyiapkan dan menyusun anggaran serta kegiatan penganggaran lainnya tidak harus ditangani sendiri oleh pimpinan tertinggi perusahaan, melainkan dapat didelegasikan kepada bagian lain dalam perusahaan.

Beberapa peneliti menyimpulkan bahwa partisipasi manajer dalam penentuan anggaran mendorong para manajer untuk mengidentifikasikan tujuan atau target, kemudia menerima anggaran secara penuh, dan melaksanakannya untuk mencapai target tersebut (Argyris, 1952; Hanson, 1966).

Penelitian Indriantoro (1993) dalam Alim (2002) membuktikan adanya hubungan positif antara partisipasi dalam penyusunan anggaran dengan kinerja manajerial. Sedangkan Brownell dan Mclnnes (1986) dengan mengembangkan instrumen yang digunakan Milani (1975) untuk mengukur partispasi dan menggunakan instrumen Mahoney et al. (1963) untuk mengukur kinerja manajerial, membuktikan bahwa partisipasi tinggi dalam penyusunan anggaran meningkatkan kinerja manajerial.

Penelitian Riyadi (2000) menemukan bukti yang berbeda dengan penelitian sebelumnya. Riyadi (2000) membuktikan bahwa motivasi kerja yang dimiliki manajer tidak mempengaruhi hubungan antara partisipasi penyusunan anggaran dan kinerja manajerial. Sedangkan variabel pelimpahan wewenang mempengaruhi hubungan partisipasi penyusunan anggaran dengan kinerja manajerial. Searfoss dan Monczka (1973) membuktikan bahwa partisipasi yang dirasakan dalam proses anggaran dan motivasi mencapai anggaran memiliki hubungan positif. Motivasi dalam penelitian Searfoss dan Monczka (1973) diukur dengan menggunakan dua dimensi yaitu "usaha mengarah pada tujuan" (goal-directing effort) dan "usaha evaluasi" (evaluative effort). Lebih lanjut, hasil penelitian Searfoss dan Monczka (1973) menemukan bahwa variabel kebutuhan independensi dan otoritas tidak memoderasi hubungan antara partisipasi dalam proses anggaran dengan motivasi untuk mencapai anggaran.

Hasil lain menemukan adanya hubungan positif antara partisipasi dalam proses anggaran dengan level organisasional. Partipasi dalam proses penyusunan anggaran juga terbukti memiliki pengaruh positif terhadap kinerja dan motivasi kerja manajerial (Govindarajan, 1986; Leslie, 1992). Namun beberapa bukti empiris menunjukkan bahwa tidak selamanya partisipasi dalam penyusunan anggaran mempunyai pengaruh positif. Penelitian Milani (1975), Bruns dan Waterhouse (1975), Brownell (1981), Riyanto (1997), Supomo (1998) menemukan bukti bahwa partisipasi anggaran tidak berpengaruh sigunifikan terhadap kinerja. Bahkan penelitian Locke dan Bryan (1967) membuktikan adanya pengaruh negatif partisipasi terhadap kinerja. 
Berdasar analisa Brownell (1982), Govindarajan (1986) dan Riyanto (1999), ditengarai ada faktor yang menyebabkan ketidakkonsistenan hasil penelitian hubungan antara partisipasi dalam penyusunan anggaran dengan kinerja. Faktor penyebab ketidakkonsistenan tersebut adalah faktor kontinjensi (Alim, 2002). Faktor kontinjensi adalah faktor atau kondisi tertentu yang dpaat mempengaruhi efektivitas partisipasi penyusunan anggaran terhadap kinerja. Menurut Govindarajan (1986), faktor kontinjensi dapat dibedakan menjadi dua yaitu faktor atribut psikologi individu dan faktor kontekstual.

Beberapa faktor kontinjensi yang sudah diteliti terhadap efektivitas partisipasi penyusunan anggaran antara lain faktor atribut psikologi individu yaitu locus of control (Brownell, 1981, 1982; Govindarajan, 1986), gaya kepemimpinan (Brownell, 1982), motivasi (Mia, 1988, 1989). Sedangkan beberapa faktor kontekstual organisasi juga telah diteliti, antara lain kesulitan tugas (Mia, 1988), budaya organisasi (Brownell, 1982), ketidakpastian tugas (Brownell dan Hirst, 1986), dan ketidakpastian lingkungan (Govindarajan, 1986; Leslie, 1992).

Penelitian-penelitian di Indonesia juga telah meneliti sejumlah faktor kontinjensi yang mempengaruhi hubungan antara partisipasi penyusunan anggaran dengan kinerja dan kepuasan kerja antara lain persepsi tugas manajer dan apresiasi lingkungan organisasi (Wirakusumah, 1987), locus of control (Indriantoro, 1993), dan budaya organisasi (Indriantoro, 1993) dalam Alim (2002), Supomo, 1998), motivasi (Riyadi, 1998) dan struktur organisasi (Supomo, 1998; Riyadi, 1998) dan lain-lain. Bertitik tolak dari hasil penelitian sebelumnya, penelitian ini berusaha menemukan bukti pengaruh faktor kontinjensi lain yaitu karakteristik personalitas seseorang atau manajer. Karakteristik personalitas yang akan diuji adalah kebutuhan akan independensi dan otoritas manajer terhadap hubungan antara partisipasi dalam penyusunan anggaran dengan kinerja manajerial.

\subsection{Anggaran dan Penganggaran}

Menurut Nafarin (2000), anggaran adalah rencana tertulis mengenai kegiatan suatu organisasi yang dinyatakan secara kuantitatif dan umumnya dalam satuan uang untuk jangka waktu tertentu. Sedangkan Munandar (1986) memberikan definisi tentang anggaran yaitu suatu rencana yang dinyatakan dalam unit (kesatuan) moneter dan berlaku untuk jangka waktu (periode) tertentu yang akan datang.

Pada umumnya definisi anggaran memiliki empat unsur yaitu:

1. Rencana: Anggaran merupakan rencana yang telah disusun untuk memberikan arah bagi perusahaan di masa yang akan datang.

2. Mencakup seluruh kegiatan perusahaan yaitu semua kegiatan yang akan dilakukan oleh seluruh bagian yang ada dalam perusahaan. Anggaran berfungsi sebagai pedoman kerja sehingga harus mencakup seluruh kegiatan perusahaan.

3. Satuan moneter. Anggaran dinyatakan dalam unit moneter yang dapat diterapkan pada berbagai kegiatan perusahaan yang beraneka ragam. Satuan moneter berguna untuk menyeragamkan semua kegiatan perusahaan yang beraneka ragam sehingga mudah untuk diperbandingkan dan dianalisa.

4. Jangka waktu tertentu. Anggaran disusun untuk jangka waktu tertentu yang akan datang sehingga memuat taksiran-taksiran tentang segala sesuatu yang akan terjadi dan akan dilakukan dimasa mendatang.

Pada dasarnya, anggaran (budget) berbeda dengan penganggaran (budgeting). Menurut Munandar (1986) penganggaran adalah proses kegiatan yang menghasilkan anggaran tersebut sebagai hasil kerja (output) serta proses kegiatan yang berkaitan dengan pelaksanaan fungsi-fungsi anggaran. Sedangkan Nafarin (2000) memberikan definisi penganggaran sebagai proses penyusunan anggaran yang dibuat untuk mencapai tujuan perusahaan dalam memperoleh laba. 


\section{Pengaruh Karakteristik Personalitas Manajer (Endang Raino Wirjono dan Agus Budi Raharjono)}

\subsection{Fungsi dan Manfaat Anggaran}

Anggaran memiliki beberapa fungsi yaitu sebagai pedoman kerja, alat pengkoordinasian kerja dan alat pengawasan kerja (Munandar, 1986). Sedangkan Supriyono (1987) menyatakan bahwa anggaran memiliki beberapa macam fungsi yaitu:

1. Fungsi Perencanaan. Anggaran memuat perencanaan awal dari penentuan tujuan, strategi dan kebijakan perusahaan.

2. Fungsi Koordinasi. Anggaran digunakan sebagai alat pengkoordinasian rencana dan tindakan berbagai unit yang ada di organisasi agar dapat bekerja secara selaras menuju arah pencapaian tujuan.

3. Fungsi Komunikasi. Dalam penyusunan anggaran, seluruh bagian dantingkatan organisasi berkomunikasi dan berperan serta dalam proses. Setiap orang dalam organisasi bertanggungjawab terhadap anggaran yang telah disusun.

4. Fungsi Motivasi. Anggaran berfungsi sebagai alat untuk memotivasi para pelaksana dalam melaksanakan tugas untuk mencapai tujuan.

5. Fungsi Pengendalian dan Evaluasi. Anggaran digunakan sebagai alat pengendalian kegiatan karena anggaran yang telah disetujui merupakan komitemen dari para pelaksana yang ikut berperan serta dalam penyusunan anggaran tersebut.

6. Fungsi Pendidikan. Anggaran berfungsi sebagai alat untuk mendidik para manajer mengenai cara bekerja secara terperinci pada pusat pertanggungjawaban yang dipimpinnya dan menghubungkannya dengan pusat pertanggungjawaban lain dalam organisasi yang bersangkutan.

Selain fungsi, anggaran juga memiliki manfaat yaitu (Anthony dan Govindrajan, 1998):

1. Anggaran digunakan untuk menentukan rencana strategic.

2. Anggaran digunakan untuk membantu pengkoordinasian aktivitas dari suatu organisasi.

3. Anggaran digunakan untuk memberikan tanggungjawab terhadap manajer agar menginformasikan kinerja manajer.

4. Anggaran digunakan untuk standar pengevaluasian aktivitas manajer.

Proses penyusunan anggaran diawali dengan pembuatan atau penentuan pedoman anggaran. Pedoman anggaran berisi kebijakan pokok organisasi yang akan disampaikan kepada manajemen untuk dijadikan sebagai dasar pengajuan usulan anggaran. Manajer sesuai dengan tanggungjawabnya masing-masing akan mengusulkan rancangan anggaran yang menjadi komponen dalam penyusunan anggaran.usulan rancangan dari para manajer akan dipertimbangkan dan ditentukan sebagai anggaran.

Rancangan yang dibuat oleh para manajer diajukan ke komite anggaran untuk dirundingkan bersamasama dan ditelaah terlebih dahulu. Negosiasi sangat diperlukan untuk menyelaraskan usulan rancangan anggaran dan disesuaikan dengan rencana jangka panjang dan tujuan organisasi yang telah ditentukan. Rancangan yang telah disetujui akan dilaksanakan dan pengawasan akan dilakukan dengan cara membandingkan dengan realisasi anggaran tersebut.

Dalam penyusunan anggaran, para perancang anggaran harus memperhatikan aspek perilaku. Ada beberapa aspek perilaku yang perlu diperhatikan dalam penyusunan anggaran (Nafarin, 2000), yaitu:

1. Anggaran harus realistis, cermat, sehingga tidak terlalu rendah atau terlalu tinggi. Anggaran yang terlalu rendah tidak mencerminkan kedinamisan, sedangkan anggaran yang terlalu tinggi tidak akan tercapai dan hanya merupakan angan-angan saja.

2. Partisipasi manajer puncak diperlukan untuk memotivasi manajer pelaksana.

3. Anggaran yang dibuat harus mencerminkan keadilan, sehingga pelaksana tidak merasa tertekan tetapi termotivasi.

4. Laporan realisasi anggaran harus akurat dan tepat waktu sehingga apabila terjadi penyimpangan dapat segera diantisipasi lebih dini. 
Ada dua pendekatan yang dapat digunakan dalam penyusunan anggaran yaitu:

1. Pendekatan top-down: dalam pendekatan ini, proses penyusunan anggaran dimulai dari manajer puncak. Anggaran diturunkan dari manajer puncak kepada bawahannya dan bawahan tersebut dituntut untuk melaksanakan anggaran tanpa ada keterlibatan dalam proses penyusunannya. Pada umumnya pendekatan ini diterapkan oleh perusahaan yang memiliki struktur organisasi sentralisasi. Kelemahan dari pendekatan ini adalah bawahan menjadi tertekan oleh pekerjaannya dan akan berperilaku tidak semestinya. Keunggulan pendekatan ini yaitu adanya dukungan yang kuat dari manajer puncak dalam pengembangan anggaran dan proses penyusunan menjadi lebih mudah dikendalikan oleh manajer puncak.

2. Pendekatan bottom-up: anggaran disusun sepenuhnya oleh bawahan dan disahkan oleh manajer puncak sebagai anggaran perusahaan. Hal yang menonjol dari pendekatan ini adalah adanya negosiasi usulan anggaran antara penyusun anggaran dengan komite anggaran. Tujuan negosiasi adalah menyatukan dua kepentingan yang berbeda. Di satu pihak, manajer puncak menginginkan anggaran yang ketat untuk menjamin perusahaan memperoleh laba yang maksimal. Di lain pihak, manajer pusat pertanggungjawaban (manajer operasi) ingin agar anggaran yang disetujui mendapat kelonggaran yang cukup dan adanya tanggapan atas masalah-masalah tak terduga atau perubahan kegiatan. Perusahaan yang memiliki struktur organisasi desentralisasi biasanya menggunakan pendekatan ini. Kelemahan dari pendekatan ini adalah dengan partisipasi yang terlalu luas sering menimbulkan konflik dan memakan waktu yang panjang dalam proses penyusunan anggaran. Sedangkan keunggulan pendekatan ini terletak pada mekanisme negosiasi yang ada antara penyusun anggaran dan komite anggaran.

3. Gabungan pendekatan top-down dan bottom-up: kerja sama dan interaksi manajer puncak dan manajer pusat pertanggungjawaban dalam menetapkan anggaran merupakan cara terbaik bagi perusahaan. Anggaran disusun oleh setiap manajer pusat pertanggungjawaban yang ada dalam perusahaan dengan berpedoman pada tujuan, strategi dan kebijakan perusahaan. Dengan demikian, kelemahan dari kedua pendekatan terdahulu dapat dikurangi sampai sekecil-kecilnya sehingga bawahan merasakan bahwa dirinya diperhitungkan dan efektivitas pelaksanaan anggaran dapat terjamin.

\subsection{Penyusunan Anggaran Partisipatif dan Konsep Kinerja}

Partisipasi adalah keterlibatan individu yang bersifat mental dan emosional dalam situasi kelompok bagi pencapaian tujuan bersama dan berbagi tanggungjawab bersama. Partisipasi yang diberikan oleh individu bukan hanya aktivitas fisik tetapi juga sisi psikologis, yaitu seberapa besar pengaruh yang dianggap memiliki seseorang dalam pengambilan keputusan.

Seseorang yang terlibat dalam pengambilan keputusan akan termotivasi dalam situasi kelompok karena diberi kesempatan untuk mewujudkan inisiatif dan daya kreatifitas. Tujuan bersama akan lebih mudah tercapai sehingga ada keterlibatan secara pribadi dan kesediaan untuk menerima tanggungjawab masing-masing.

Penyusunan anggaran partisipatif pada dasarnya mengijinkan manajer bawahan mempertimbangkan cara pembentukan anggaran (Hansen dan Mowen, 2004). Zimmerman (1995) dalam Alim (2002) menyatakan bahwa penyusunan anggaran partisipatif merupakan anggaran bottom-up yang melibatkan bawahan secara penuh untuk bertanggungjawab memenuhi target yang telah ditentukan dalam anggaran.

Adanya rasa tanggungjawab manajer level lebih rendah dapat memperkuat kreativitas manajer yang bersangkutan. Apabila manajer level lebih rendah diberi kesempatan untuk menyusun anggaran maka tujuan anggaran dapat menjadi tujuan personal dan akan menghasilkan goal congruence yang lebih besar.

Partipasi anggaran juga akan memotivasi level lebih rendah sehingga bersedia menerima dan mencapai target serta skema pengendalian. Survey yang dilakukan oleh Standard and Poor's 500 Vs Companies terhadap 98 responden menyebutkan bahwa anggaran partisipatif lebih sering digunakan ketika manajer level lebih rendah memiliki pengetahuan yang lebih dibandingkan manajemen pusat (Zimmerman, 1995 dalam Alim, 2002).

Para pendukung model anggaran partisipatif mengklaim bahwa peningkatan tanggungjawab dan tantangan yang inheren dalam proses penyediaan insentif non moneter yang bisa menimbulkan tingkat kinerja dan 
kepuasan yang lebih tinggi. Individu yang terlibat dalam penyusunan anggaran akan bekerja lebih keras untuk mencapainya.

Menurut Mulyadi (1993) budgeting participation adalah suatu proses pengambilan keputusan bersama oleh dua belah pihak atau lebih yang mempunyai dampak masa depan bagi pembuat keputusan tersebut. Oleh karena itu, pembuat keputusan melibatkan banyak pihak yang terkait dalam keputusan tersebut sehingga dampaknya dapat dirasakan oleh semua pihak.

Para individu turut terlibat dan memiliki pengaruh dalam penentuan target anggaran dalam penyusunan anggaran partisipatif. Kinerja para individu akan dievaluasi dan dihargai berdasarkan pencapaian target anggaran yang telah ditetapkan.

Menurut Gibson (1989) dalam Alim (2002) kinerja adalah hasil yang diinginkan dari perilaku kinerja individu sebagai dasar kinerja organisasi.

Oleh karena itu, penilaian kinerja individu dilakukan berdasar kinerja individu. Setelah itu akan dilakukan penilaian kinerja secara kelompok dalam organisasi.

Menurut Handoko (1995), ada dua konsep utama untuk mengukur kinerja sesorang atau karyawan, yaitu efektifitas dan efisiensi. Kinerja karyawan yang efektif dan efisien dapat menambah produktivitas karyawan itu sendiri sehingga dapat menambah produktivitas perusahaan.

Penilaian kinerja dapat mempertinggi produktivitas para karyawan. Akan tetapi, penilaian kinerja harus dilaksanakan sebaik mungkin sehingga dapat meningkatkan komitmen karyawan untuk lebih produktif. Penilaian yang baik akan membuat karyawan merasa dihargai sehingga karyawan akan termotivasi untuk lebih meningkatkan kinerja.

\subsection{Pendekatan Kontijensi}

Indriantoro (1993) dalam Supomo (1998) menemukan hubungan positif signifikan antara partisipasi penyusunan anggaran dengan kinerja manajerial. Sedangkan penelitian Supomo (1998) menunjukkan partisipasi penyusunan anggaran tidak mempunyai pengaruh secara langsung terhadap kinerja manajerial.

Govindarajan (1986) menyarankan untuk menyelesaikan pertentangan dari berbagai hasil penelitian terdahulu, dapat digunakan pendekatan kontinjensi. Pendekatan kontinjensi memungkinkan variabel-variabel lain menjadi variabel moderating (faktor yang mempengaruhi hubungan antara dua variabel) atau intervening (faktor yang dipengaruhi oleh suatu variabel dan mempengaruhi variabel lainnya) yang mempengaruhi hubungan partisipasi penyusunan anggaran dengan kinerja manajerial (Murray, 1990; Shield dan Young, 1993).

Supomo (1998) menguji pengaruh variabel moderating yaitu struktur dan budaya organisasi terhadap efektifitas partisipasi penyusunan anggaran dalam peningkatan kinerja manajerial. Penelitian Poerwati (2002) membuktikan bahwa partisipasi penyusunan anggaran tidak berpengaruh secara langsung terhadap kinerja manajerial. Sedangkan variabel budaya organisasi yang berorientasi pada orang memiliki pengaruh moderating terhadap hubungan partisipasi penyusunan anggaran dan kinerja manajerial. Variabel motivasi terbukti tidak mempunyai pengaruh moderating terhadap hubungan antara partisipasi penyusunan anggaran dan kinerja manajerial.

Berdasarkan hasil temuan-temuan ini mengindikasikan bahwa efektifitas partisipasi penyusunan anggaran memang dipengaruhi oleh faktor-faktor kondisional organisasi. Penelitian Hariyanti dan Nasir (2002) menemukan bukti bahwa variabel kecukupan anggaran dan komitmen organisasi merupakan variabel intervening dalam hubungan antara partisipasi penyusunan anggaran dengan kinerja manajerial. Faktor kontinjensi lain yang pernah diteliti oleh Searfoss dan Monczka (1973) adalah karakteristik personalitas manajer yaitu kebutuhan akan independensi dan otoritas. Searfoss dan Monczka (1973) membuktikan bahwa kebutuhan akan independensi dan otoritas tidak memoderasi hubungan antara partisipasi penyusunan anggaran dengan motivasi mencapai anggaran.

Penelitian ini menggunakan faktor kontinjensi yaitu variabel karakteristik personalitas yaitu kebutuhan akan independensi dan otoritas manajer, tetapi tidak dikaitkan dengan motivasi mencapai anggaran. Penelitian ini 
akan menguji pengaruh variabel kebutuhan akan independensi dan otoritas terhadap hubungan antara partisipasi penyusunan anggaran dengan kinerja manajerial.

Seseorang yang memiliki karakteristik personalitas menghendaki independensi dan otoritas akan merasa dihargai ketika berpartisipasi dalam proses penyusunan anggaran. Adanya partisipasi akan memacu manajer untuk meningkatkan kinerjanya. Partipasi memberikan kesempatan pada manajer level lebih rendah untuk menjalankan anggaran yang dapat dicapai secara lebih mudah. Berdasarkan paparan tersebut, hipotesis alternatif yang diajukan dalam penelitian ini adalah:

H1: Kebutuhan akan independensi berpengaruh terhadap hubungan antara partisipasi penyusunan anggaran dengan kinerja manajerial

H2: Kebutuhan akan otoritas berpengaruh terhadap hubungan antara partisipasi penyusunan anggaran dengan kinerja manajerial

\section{METODA PENELITIAN}

\subsection{Sampel dan Pengumpulan Data}

Metodologi yang digunakan dalam penelitian ini mencakup beberapa prosedur pengujian. Pertama, akan digunakan statistik deskriptif untuk mengetahui besarnya mean dari variabel-variabel yang digunakan dalam penelitian ini. Tahap berikutnya adalah membuktikan adanya pengaruh masing-masing variabel terhadap hubungan anggaran partisipatif dengan kinerja manajerial.

Teknik penyampelan yang digunakan dalam penelitian ini adalah nonprobabilistic sampling yaitu setiap elemen dalam populasi tidak memiliki probabilitas yang sama untuk menjadi sampel. Teknik penentuan sampel secara non probabilitas yang digunakan dalam penelitian ini adalah purposive sampling.

Sampel pada penelitian ini adalah manajer dari berbagai perusahaan yang memiliki anggaran. Sebagian data dikumpulkan dengan cara personally administered questionnaire yakni suatu metode pengumpulan sampel dengan menyebarkan kuesioner pada sekelompok responden secara langsung. Banyak keuntungan dengan menggunakan metode jenis ini, yakni: dapat memotivasi responden, responden dengan cepat dan mudah dapat mengklarifikasi item-item pernyataan kuesioner jika memang perlu adanya klarifikasi, lebih murah dibanding mail questionnaire, tingkat pengembalian tinggi dan anonimitas responden terjamin. Namun demikian, dengan pertimbangan jarak, ada beberapa data yang dikumpulkan via pos atau email.

\subsection{Data Demografi Responden}

Dalam penelitian ini disebarkan sebanyak 200 buah kuesioner dengan responsi sebesar 100 buah (50 persen). Dari jumlah tersebut, sebanyak 15 buah tidak dapat diolah karena data kurang lengkap. Total kuesioner yang dapat diolah sebesar 85 buah. Data demografi responden dapat dilihat dalam tabel. 1.

Tabel 1.

Data Demografi Responden

\begin{tabular}{llcc}
\hline \multirow{2}{*}{ Keterangan } & \multicolumn{1}{c}{ Kategori } & \multicolumn{2}{c}{ Responden } \\
& & Jumlah & Persentase \\
\hline \multirow{2}{*}{ Jenis kelamin } & Wanita & 38 & 44.7 \\
& Pria & 47 & 55.3 \\
& Di bawah 30 tahun & 3 & 3.5 \\
Usia & $31-35$ tahun & 16 & 18.8 \\
& $36-40$ tahun & 27 & 31.8 \\
& $41-45$ tahun & 24 & 28.2 \\
& 45 tahun ke atas & 15 & 17.6
\end{tabular}




\begin{tabular}{llrr} 
& Level rendah & 14 & 16.5 \\
\multirow{3}{*}{ Jabatan } & Level menengah & 39 & 45.9 \\
& Level tinggi & 32 & 37.6 \\
\multirow{3}{*}{ Lama bekerja } & $1-3$ tahun & 17 & 9.4 \\
& Di atas 3 - 6 tahun & 35 & 20 \\
& Di atas 6 - 9 tahun & 25 & 41.2 \\
& Lebih dari 9 tahun & 29.4 \\
\hline
\end{tabular}

Sumber: Data Primer diolah

\subsection{Definisi Operasional Variabel dan Pengukuran}

Definisi operasional dan instrument-instrumen pengukuran yang digunakan dalam penelitian ini berdasarkan pada penelitian sebelumnya dan dimodifikasi untuk penyesuaian terhadap penelitian ini.

\section{Partisipasi dalam penyusunan anggaran}

Partisipasi dalam penyusunan anggaran merupakan keterlibatan manajer dalam proses penyusunan anggaran pada pusat pertanggungjawaban yang dipimpinnya. Instrumen partisipasi terdiri dari 15 butir pernyataan yang dikembangkan oleh Fertakis (1967) dalam Searfoss dan Monczka (1973). Responden diminta memberikan persetujuan terhadap pernyataan yang ada dengan memilih salah satu dari lima poin skala likert. Skor yang rendah menunjukkan bahwa partisipasi tinggi, sedangkan skor tinggi menunjukkan partisipasi rendah.

\section{Kebutuhan akan independensi (need for independence)}

Variabel ini merupakan variabel pemoderasi dalam penelitian ini. Kebutuhan akan independensi menunjukkan tingkat otonomi yang diinginkan oleh responden. Variabel ini mewakili karakteristik personalitas yang mungkin berpengaruh terhadap hubungan antara partisipasi dengan kinerja. Kebutuhan akan independensi diukur oleh Vroom dan dikembangkan oleh Tannenbaum dan Allport dalam Searfoss dan Monczka (1976) yang terdiri dari 12 pernyataan.

\section{Otoritas}

Kebutuhan akan otoritas menunjukkan tingkat otoritas yang diinginkan oleh responden. Variabel ini merupakan variabel pemoderasi yang diduga dapat mempengaruhi hubungan antara partisipasi dengan kinerja manjerial. Pengukuran tingkat otoritas dilakukan dengan menggunakan kuesioner yang dikembangkan oleh Vrom dalam Searfoss daan Monczka (1973).

\section{Kinerja Manajerial}

Kinerja manajerial merupakan tingkat kecakapan manajer dalam melaksanakan aktivitas manajemen yang meliputi perencanaan, pengkoordinasian, investigasi, pengaturan, negosiasi, perwakilan, pengawasan dan evaluasi. Pengukuran variabel kinerja manajerial dengan menggunakan instrument yang dikembangkan oleh Mahoney et al. (1963). Instrument diukur dengan skala Likert lima poin.

\subsection{Analisis Data}

Langkah pertama dalam analisis meliputi penetapan reliabilitas ukuran yang digunakan dalam mengoperasionalkan variabel penelitian. Sedangkan untuk menguji hipotesis penelitian menggunakan regresi berganda.

Uji reliabilitas dilakukan untuk mengetahui sejauh mana hasil pengukuran tetap konsisten, jika dilakukan pengukuran dua kali atau lebih terhadap gejala yang sama dengan menggunakan alat ukur yang sama, uji reliabilitas dilakukan dengan menghitung cronbach alpha dari masing-masing instrumen dalam suatu variabel. 
Instrumen yang dipakai dikatakan andal (reliable) jika memiliki nilai cronbach alpha lebih dari 0,6 (Nunnaly, 1978 dalam Ghozali, 2001).

Uji validitas digunakan untuk mengukur sah atau valid tidaknya suatu kuesioner. Suatu kuesioner dikatakan valid apabila pertanyaan pada kuesioner mampu untuk mengungkapkan sesuatu yang akan diukur oleh kuesioner tersebut. Analisis Faktor digunakan untuk menguji apakah butir-butir pertanyaan atau indikator yang digunakan dapat mengkonfirmasi sebuah konstruk atau variabel. Jika masing-masing butir pertanyaan merupakan indikator sebuah variabel maka akan memiliki nilai loading factor yang tinggi. Dengan melihat rotasi varimax, dapat dikelompokkan butir-butir pertanyaan yang masuk dalam kelompok variabel atau konstruk tertentu. Uji validitas juga dapat dilakukan dengan melihat nilai Kaiser MSA yang lebih besar dari 0,4.

Hipotesis pertama dan kedua diuji menggunakan moderated regression analysis. Variabel pemoderasi dalam penelitian ini akan diuji dengan melihat kenaikan $r$ squared dari model pertama ke model kedua. Persamaan regresi yang digunakan untuk menguji hipotesis pertama dan kedua sebagai berikut:

$$
\begin{aligned}
& \mathrm{KM}=\alpha+\beta_{1} \text { PART }+\beta_{2} \mathrm{KI}+\beta_{3} \mathrm{KO}+\varepsilon \\
& \mathrm{KM}=\alpha+\beta_{1} \text { PART }+\beta_{2} \mathrm{KI}+\beta_{3} \mathrm{KO}+\beta_{4} \text { PART } \times \mathrm{KI}+\varepsilon \\
& \mathrm{KM}=\alpha+\beta_{1} \text { PART }+\beta_{2} \mathrm{KI}+\beta_{3} \mathrm{KO}+\beta_{4} \text { PART } \times \mathrm{KO}+\varepsilon
\end{aligned}
$$

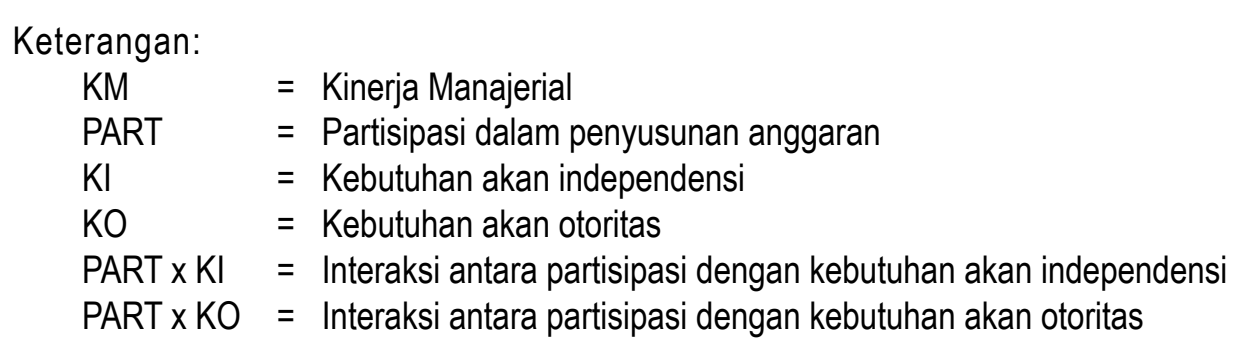

Pengujian hipotesis dilakukan dengan melihat signifikansi koefisien masing-masing variabel independen terhadap variabel dependen. Kemudian model akan diuji kemampuan prediksinya dengan melihat nilai $r$ squared.

\section{HASIL ANALISIS DAN PEMBAHASAN}

\subsection{Uji Reliabilitas dan Validitas}

Kualitas data dalam suatu pengujian hipotesis akan mempengaruhi hasil ketepatan uji hipotesis. Kualitas data yang dihasilkan dari penggunaan instrumen penelitian dapat dievaluasi dengan uji reliabilitas dan uji validitas. Uji reliabilitas ditujukan untuk mengetahui konsistensi hasil pengukuran jika dilakukan pengukuran dua kali atau lebih terhadap gejala yang sama dengan menggunakan alat ukur yang sama. Uji reliabilitas dilakukan dengan cara menghitung cronbach alpha dari masing-masing instrumen dalam suatu varaibel. Instrumen untuk mengukur masing-masing variabel dikatakan reliable jika memiliki cronbach alpha $>0,5$ (Ghozali, 2001).

Berdasarkan uji reliabilitas, instrumen-instrumen yang digunakan dalam penelitian ini reliabel. Ringkasan nilai cronbach alpha yang seluruhnya lebih besar dari 0,5 untuk masing-masing variabel dapat dilihat dalam tabel 4. 1 (hasil selengkapnya dapat dilihat dalam lampiran 1, 2, 3 dan 4). Variabel Kebutuhan akan independensi (KI) memiliki nilai cronbach alpha sebesar 0,7348, variabel Kebutuhan akan Otoritas (KO) memiliki nilai cronbach alpha sebesar 0,6739, variabel Partisipasi (PART) sebesar 0,7331, dan variabel Kinerja Manajerial (KM) memiliki nilai cronbach alpha sebesar 0,6271. Berdasarkan nilai cronbach alpha masing-masing butir pernyataan dalam kuesioner penelitian ini terbukti dapat diandalkan (reliabel). 
Tabel 2.

Hasil Uji Reliabilitas dan Validitas

\begin{tabular}{lr}
\hline \multicolumn{1}{c}{ Variabel } & Nilai Cronbach Alpha \\
\hline Kebutuhan akan independensi & 0,7348 \\
Kebutuhan akan otoritas & 0,6739 \\
Partisipasi & 0,7331 \\
Kinerja manajerial & 0,6271 \\
\hline
\end{tabular}

Sumber: data primer diolah

Pengujian validitas dilakukan untuk mengetahui validitas butir-butir pernyataan yang terdapat dalam kuesioner. Pengujian validitas juga ditujukan untuk mengetahui kecermatan suatu alat uji dalam melakukan fungsi pengukuran. Dalam penelitian ini, pengujian validitas secara statistik tidak dilakukan karena instrumen yang digunakan untuk mengukur variabel-variabel dalam penelitian ini sudah digunakan dalam penelitian-penelitian sebelumnya.

\subsection{Pengujian Hipotesis dan Pembahasan}

Pengujian hipotesis dalam penelitian ini menggunakan analisis regresi berganda. Sebelum melakukan analisis regresi, data yang digunakan dalam penelitian ini akan diuji normalitas. Uji normalitas data dalam penelitian ini menggunakan normal probability plot yaitu membandingkan distribusi kumulatif data sesungguhnya dengan distribusi kumulatif data normal. Distribusi normal akan membentuk satu garis lurus diagonal, dan plot data akan dibandingkan dengan garis diagonal. Apabila data berdistribusi normal maka garis yang menggambarkan data sesungguhnya akan mengikuti pola garis diagonal. Hasil uji normalitas dapat dilihat dalam plot yang ada di lampiran 5.

Hipotesis yang akan diuji dalam penelitian ini ada dua yaitu pertama, kebutuhan akan independensi berpengaruh terhadap hubungan antara partisipasi penyusunan anggaran dengan kinerja manajerial; kedua, kebutuhan akan otoritas berpengaruh terhadap hubungan antara partisipasi penyusunan anggaran dengan kinerja manajerial. Kedua hipotesis akan diuji secara bertahap dengan menggunakan regresi berganda. Hipotesis pertama dan kedua akan didukung apabila terdapat kenaikan $r$ squared. Pengujian hipotesis pertama dilakukan dengan membandingkan nilai $r$ squared persamaan regresi satu dengan persamaan regresi dua. Hipotesis pertama akan didukung apabila ada peningkatan $r$ squared. Pengujian hipotesis kedua juga dilakukan dengan membandingkan persamaan regresi satu dengan persamaan regresi tiga. Apabila terdapat kenaikan $r$ squared maka hipotesis kedua akan didukung.

\section{Hipotesis Pertama}

Hasil analisis regresi persamaan satu dan dua yang digunakan dalam penelitian ini untuk membuktikan hipotesis pertama bisa dilihat dalam tabel 2. berikut ini: 
Tabel 3.

Hasil Analisis Regresi untuk Pengujian Hipotesis Pertama

\begin{tabular}{|c|c|c|c|c|}
\hline $\begin{array}{l}\text { Model } \\
\text { regresi }\end{array}$ & Persamaan regresi (sign.) & $\begin{array}{l}\text { Nilai F } \\
\text { (sign.) }\end{array}$ & R squared & $\begin{array}{c}\text { Kenaikan r } \\
\text { Squared }\end{array}$ \\
\hline 1 & $\begin{array}{c}\mathrm{KM}=-1,959+0,341 \mathrm{PART}+0,2190 \mathrm{KI} \\
(0,000) \quad(0,001) \\
+0,219 \mathrm{KO} \\
(0,001)\end{array}$ & $\begin{array}{c}2849,884 \\
(0,000)\end{array}$ & 0,990 & \\
\hline 2 & $\begin{array}{c}\mathrm{KM}=-10,273+0,456 \mathrm{PART}+0,377 \mathrm{KI} \\
(0,000) \quad(0,000) \\
+0,238 \mathrm{KO}+-0,00028 \mathrm{PART} \times \mathrm{KI} \\
(0,000) \quad(0,008)\end{array}$ & $\begin{array}{c}2306,060 \\
(0,000)\end{array}$ & & Ada \\
\hline
\end{tabular}

Sumber: data primer diolah

Persamaan satu menunjukkan bawa model regresi dapat digunakan untuk memprediksi kinerja manajerial. $\mathrm{Hal}$ ini terbukti dari nilai $\mathrm{F}$ yang signifikan pada level $0,00(<0,01)$. Koefisien determinasi ( $\mathrm{r}$ square) persamaan satu sebesar 0, 990, artinya variabel kinerja manajerial (KM) dapat dijelaskan oleh variabel kebutuhan akan independensi (KI), kebutuhan akan otoritas (KO), dan partisipasi (PART).

Koefisien regresi variabel $\mathrm{KI}, \mathrm{KO}$ dan PART menunjukkan signifikansi sebesar $0,00(<0,01)$, artinya tiga variabel ini memiliki pengaruh terhadap kinerja manajerial dalam penyusunan anggaran. Hal ini konsisten dengan hasil penelitian sebelumnya (Searfoss dan Monczka, 1976).

Berdasarkan hasil persamaan regresi satu dan dua, terdapat kenaikan r squared sebesar 0,001 (0,991 $0,990)$. Kenaikan $r$ squared menunjukkan bahwa interaksi antara partisipasi dengan kebutuhan akan independensi berpengaruh terhadap kinerja manajerial Dengan demikian, hipotesis pertama dapat didukung.

\section{Hipotesis Kedua}

Hasil analisis regresi persamaan satu dan tiga yang digunakan dalam penelitian ini untuk membuktikan hipotesis pertama bisa dilihat dalam tabel 3 berikut ini:

Tabel 4.

Hasil Analisis Regresi untuk Pengujian Hipotesis Kedua

\begin{tabular}{|c|c|c|c|c|}
\hline $\begin{array}{l}\text { Model } \\
\text { regresi }\end{array}$ & Persamaan regresi (sign.) & $\begin{array}{l}\text { Nilai F } \\
\text { (sign.) }\end{array}$ & R squared & $\begin{array}{c}\text { Kenaikan r } \\
\text { Squared }\end{array}$ \\
\hline 1 & $\begin{array}{c}\mathrm{KM}=-1,959+0,341 \mathrm{PART}+0,2190 \mathrm{KI} \\
(0,000) \\
+0,219 \mathrm{KO} \\
(0,001)\end{array}$ & $\begin{array}{l}2849,884 \\
(0,000)\end{array}$ & 0,990 & \\
\hline 3 & 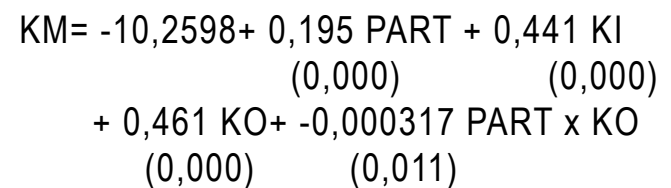 & $\begin{array}{l}2291,956 \\
(0,000)\end{array}$ & 0,991 & Ada \\
\hline
\end{tabular}

Sumber: data primer diolah 


\section{Pengaruh Karakteristik Personalitas Manajer (Endang Raino Wirjono dan Agus Budi Raharjono)}

Persamaan satu menunjukkan bawa model regresi dapat digunakan untuk memprediksi kinerja manajerial. $\mathrm{Hal}$ ini terbukti dari nilai $\mathrm{F}$ yang signifikan pada level $0,00(<0,01)$. Koefisien determinasi ( $r$ square) persamaan satu sebesar 0, 990, artinya variabel kinerja manajerial (KM) dapat dijelaskan oleh variabel kebutuhan akan independensi (KI), kebutuhan akan otoritas (KO), dan partisipasi (PART).

Koefisien regresi variabel $\mathrm{KI}, \mathrm{KO}$ dan PART menunjukkan signifikansi sebesar $0,00(<0,01)$, artinya tiga variabel ini memiliki pengaruh terhadap kinerja manajerial dalam penyusunan anggaran. Hal ini konsisten dengan hasil penelitian sebelumnya (Searfoss dan Monczka, 1976).

Berdasarkan hasil persamaan regresi satu dan tiga, terdapat kenaikan $r$ squared sebesar $0,001(0,991$ - 0,990). Kenaikan $r$ squared menunjukkan bahwa interaksi antara partisipasi dengan kebutuhan akan otoritas berpengaruh terhadap kinerja manajerial . Dengan demikian, hipotesis kedua dapat didukung.

\section{PENUTUP}

Kesimpulan yang diperoleh dari hasil penelitian ini adalah interaksi antara kebutuhan akan independensi dengan partisipasi dalam penyusunan anggaran memiliki pengaruh terhadap kinerja manajerial; dan interaksi antara kebutuhan akan otoritas dengan partisipasi dalam penyusunan anggaran memiliki pengaruh terhadap kienrja manajerial. Akan tetapi, penelitian ini masih memiliki beberapa keterbatasan, antara lain: satu, responden yang digunakan dalam penelitian ini tidak melihat karakteristik dan klasifikasi jenis industri; dua, manajer yang dipilih sebagai responden tidak dibedakan menurut ukuran perusahaan; tiga, penilaian kinerja manajerial dalam penyusunan anggaran menggunakan self rating sehingga bisa menimbulkan bias; dan empat, analisis yang digunakan hanya model regresi sederhana sehingga tidak dapat menggambarkan hubungan masing-masing butir pernyataan dalam konstruk terhadap kinerja manajerial.

Penelitian-penelitian mendatang diharapkan dapat memperbaiki kelemahan-kelemahan penelitian ini yaitu, sampel yang diambil dapat diperluas di area geografis yang lain sehingga hasil dapat digeneralisasi, dan alat analisis yang digunakan dapat menggunakan Structural Equation Model (SEM) untuk mengetahui hubungan tiap butir dalam konstruk.

\section{DAFTAR PUSTAKA}

Alim, Mohammad Nizarul, (2002), "Pengaruh Ketidakpastian Stratejik dan Revisi Anggaran terhadap Efektivitas Partisipasi Penyusunan Anggaran: Pendekatan Kontinjensi", Prosiding, Simposium Nasional Akuntansi $\mathrm{V}$, Semarang.

Anthony, R. N., and V. Govindarajan, (1998), Management Control System, ninth edition, Boston, McGraw-Hill Company.

Argyris, C., (1952), Human Problems With Budget, Harvard Business Review.

Brownell, P., (1981), "Participation in Budgeting, Locus of Control and Organizational Effectiveness", The Accounting Review, October.

Brownell, P., (1982), "A Field Study Examination of Budgetary Participation and Locus of Control", The Accounting Review, pp. 766-777.

Brownell, P., and M. Hirst, (1986), "Reliance onAccounting Information, Budgetary Participation and Task Uncertainty: Tests of A Three Way Interaction", Journal of Accounting Research 24 (2), pp. 241-249.

Bruns, W. J., and J. H. Waterhouse, (1975), "Budgetary Control and Organization Structure", Journal of Accounting Research, Autumn, pp. 177-203. 
Covaleski, M. A., J. H. Evans III, Joan L. Luft, and M. D. Shields, (2003), "Budgeting Research: Three Theoretical Perspective and Criteria for Selective Integration", Journal of Management Accounting Research, (15), pp. 3-49.

Ghozali, Imam (2001), Aplikasi Analisis Mutivariate dengan Program SPSS, Badan Penerbit Universitas Diponegoro.

Govindarajan, V., (1986), "Impact of Participation in The Budgetary Process on Managerial Attitude and Performance: Universalistic and Contingency Persepective", Decision Science.

Handoko, Hani, (1995), Manajemen, BPFE Yogyakarta.

Hansen, Don R., and M. Mowen, (2004), Management Accounting, $7^{\text {th }}$ edition, South Western College Publishing.

Hanson, Ernest I., (1996), "The Budgetary Control Function", The Accounting Review, April, pp. 239-243.

Hariyanti, W., dan M. Nasir, (2002), "Pengaruh Partisipasi Penyusunan Anggaran terhadap Kinerja Manajerial: Peran Kecukupan Anggaran dan KOmitmen Organisasi sebagai Variabel Intervening", Prosiding, Simposium Nasional Akuntansi V, Semarang.

Kennis, I., (1979), "Effects of Budgetary Goal Chararcteristics on Managerial Attitudes and Performance", The Accounting Review, April.

Kurnianingsih, R., dan Nur Indriantoro, (2001), "Pengaruh Sistem Pengukuran Kinerja dan Sistem Penghargaan terhadap Keefektifan Penerapan Teknik Total Quality Management (Studi Empiris pada Perusahaan Manufaktur di Indonesia)", Jurnal Riset Akuntansi Indonesiâ, (4:1), Januari.

Leslie, Kren, (1992), "Budgetary Participation and Managerial Performance: The Impact of Information and Environmental Volatility", The Accounting Review, (76:3).

Locke, E. A., and J. F. Bryan, (1967), "Performance Goals as Determinants of Level of Performance and Boredom", Journal of Applied Psychology 51, pp. 120-130.

Luft, J., and M. Shields, (2003), "Mapping Management Accounting: Graphics and Guidelines for Theory-Consistent Empirical Research", Accounting, Organizations and Society, 28.

Mahoney, T. A., T. H. Jerdee, and S. J. Carrol, (1963), Development of Managerial Performance: A Research Approach, O. H. Cincinnati, Southwestern Publishing Co.

Mia, Lokman, (1988), "Managerial Attitude, Motivation and The Effectiveness of Budget Participation", Accounting Organization and Society, (13:5).

Milani, K., (1975), "The Relationship of Participation in Budget-Setting to Industrial Supervisor Performance and Attitudes: A Field Study", The Accounting Review 50, April.

Mulyadi, (1993), Akuntansi Manajemen: Konsep, Manfaat dan Rekayasa, BP STIE YKPN, Yogyakarta

Munandar, M., (1986), Budgeting (Perencanaan, Pengkoordinasian dan Pengawasan Kerja), BPFE, Yogyakarta

Murray, Dennis, (1990), "The Performance Effects of Participative Budgeting an Integration of Intervening and Moderating Variables", Behavioral Research in Accounting (2).

Nafarin, M., (2000), "Penganggaran Perusahaan, Edisi 1, Penerbit Salemba Empat, Jakarta.

Pasoloran, O., (2002), "Pengaruh Perceived Uncertainty (PEU) terhadap Hubungan Antara Karakteristik Sasaran Penganggaran dengan Kinerja Manajerial (Studi Empiris pada Kawasan Industri Manufakturl)", Prosiding, Simposium Nasional Akuntansi V, Semarang. 
Poerwati, T., (2002), :Pengaruh Partisipasi Penyusunan Anggaran terhadap Kinerja Manajerial: Budaya Organisasi dan Motivasi sebagai Variabel Moderating", Prosiding, Simposium Nasional Akuntansi V, Semarang.

Riyadi, Slamet, (2000), "Motivasi dan pelimpahan Wewenang sebagai Variabel Moderating dalam Hubungan Antara Partisipasi Penyusunan Anggaran dan Kinerja Manajerial", Jurnal Riset Akuntansi Indonesia, (3:2), Juli.

Riyanto, Bambang, (1997), "Strategic Uncertainty, Management Accounting and Performance: An Empirical Investigation of A Contingency Theory at The Firm Level", Jurnal Riset Akuntansi, Manajemen, Ekonomi, $(1: 1)$.

Searfoss, D. G., and R. M. Monczka, !973), "Perceived Participation in The Budget Process and Motivation to Achieve Budget", Academy of Managemnt Journal, December, pp. 541-554.

Shield, M. D., and S. M. Young, (1993), "Antecedent and Consequences of Participative Budgeting: Evidence on The Effects of Assymmetrical Information", Journal of International Business Studies.

Supomo, Bambang, (1998), "Pengaruh Struktur dan Kultur Organisasi Terhadap Keefektifan Anggaran Partisipatif Dalam Peningkatan Kinerja Manajerial: Studi Empiris pada Perusahaan Manufaktur di Indonesia", Tesis tidak dipublikasikan, Program Pasca Sarjana, Universitas Gadjah Mada Yogyakarta.

Supriyono, (1987), Akuntansi Manajemen I; Konsep Dasar Akuntansi Manajemen dan Proses Perencanaan, edisi 1 BPFE, Yogyakarta.

Usry, Hammer, Carter, (2002), Cost Accounting: Planning and Control, $13^{\text {th }}$ edition, South-Western Publishing Company, Cincinnati, Ohio. 